\title{
Antimicrobial Effect of Essential Oil of Ziziphora tenuior on Water by Heterotrophic Plate Counts Method in Kerman (Southeast of Iran)
}

\author{
Amin Ganjali, Maryam Pourramezani Harati, and Massoud Kaykhaii
}

\begin{abstract}
The increasing demands of consumers for using less chemical preservatives has led to increasing number of researches to produce natural compounds with antimicrobial properties. Fresh aerial parts of wild Ziziphora tenuior were collected in Eastern Iran. Z.tenuior samples were collected after initial preparation isolated from the aboveground plant parts and plant samples preparation by water distillation using Clevenger apparatus after determining the optimal conditions for making essential oil was obtained. Essential oil with an efficiency of $1 / 1$ percent $(\mathrm{g} / \mathrm{g})$ was obtained and by GC-MS to determine the composition of the essential oils was analyzed and indicates 21 compounds. Key combinations were as: pulegone $(82.6 \%)$ and limonene $(6.8 \%)$ which was extracted. the studied essential oil would exhibit good antimicrobial properties, this essential oil in $0.08 \mathrm{ml}$ concentration could eliminate microorganisms in water. but this was not evaluated and further investigation should be carried out for use of this essential oil in various industries.
\end{abstract}

Index Terms-Ziziphora tenuior, antimicrobial, essential oil, GC-MS, heterotrophic plate counts method.

\section{INTRODUCTION}

The increasing demands of consumers for using less chemical preservatives has led to increasing number of researches to produce natural compounds with antimicrobial properties [1]. Using essential oils of plants, known as natural compounds, is expanding since these compounds have significant antimicrobial effects on a wide range of microorganisms [2]. Lamiaceae family of plants has been used as spice in foods and as medicine for digestion and combatting viral diseases [3]. This tribe includes 46 genera and 410 species and sub species in Iran. Ziziphora tenuira belongs to lamiaceae tribe, lamiales order and asteridae subclass [4].

This plant is an herbaceous, annual, 5 to $15 \mathrm{~cm}$ high with a short stem. Its leaves are narrow and pointed with short internodes. Its flowers are small, pale purple or violet. Geographical distribution is in Iran, Turkey, Russia,

Manuscript received October 27, 2014; revised February 25, 2015. This work was supported in Department of Experimental Science of Islamic Azad University, Kahnooj Branch.

A. Ganjali is with the Department of Experimental Science, Islamic Azad University, Kahnooj Branch, Kahnooj, Iran (e-mail: Amin.Ganjali@ kahnoojiau.ac.ir).

M. Pourramezani Harati is with Young Researchers and Elite Club, Kahnooj Branch, Islamic Azad University, Kahnooj, Iran (e-mail: Maryam. Pourramazani@gmail.com).

M. Kaykhaii is with Department of Chemistry, University of Sistan and Baluchestan, Zahedan, Iran (e-mail: kaykhaii@hamoon.usb.ac.ir).
Turkmenistan, Afghanistan, Pakistan, Caucasus and Siberia [5]. A substance, which is mainly seen in the essential oils from lamiaceae family including Z.tenuira, is pulgone. Pulgone owns antibacterial and antifungal properties [6]. The substance can also prevent the growth of candida albicans and salmonella typhimurium. Meanwhile, their effect on candida albicans is twice Nastatine [7].

Due to the existence of compounds such as pulgone, the essential oil compounds of Ziziphora species have been repeatedly studied in varying vegetative and weather conditions around the world. The results of the analysis of gas chromatography in a research revealed the existence of 22 different compounds in the essential oil of this herb. 5 of these compounds formed more than $73 \%$ of the essential oil and pulgone was the most [8]. Gozed et al. examined the antibacterial activity of Z.tenuior subsp, native to Turkey. The study by Gozed was conducted in laboratory conditions and on 8 species of bacteria. It showed that the essential oil of this species considerably prevented the growth of microorganisms [9]. Javidnia et al studied the composition and antimicrobial activities of the essential oil of a population of Z.tenuior in Iran. The essential oil compounds of these species were studied using GC and GC-MS and the results demonstrated that pulgone was the main compound in the essential oil of the species [10].

Plants and their essential oils are potentially useful sources of antimicrobial compounds. Numerous studies have been published on the antimicrobial activities of plant compounds against many different types of microbes [11]-[14]. Also essential oils are known to possess antimicrobial activity, which has been evaluated mainly in liquid medium. Systematic evaluation of the vapour activity was first reported by Maruzzella et al. and Kienholz in 1959, using the inverted Petri dish technique [15]-[17].

Regarding the importance of Z.tenuior species in terms of medical, health and food purposes, the presented study was carried out with the aim of investigating the effect of warm and dry climate (weather conditions of Kahnooj, Iran) on the quality and the essential oil compounds of Z.tenuior and study and examine antimicrobial effects of essential oils of aerial parts of Z.tenuior by HPC method.

\section{MATERIALS AND METHODS}

In this study, after collecting and essential oils of plants, the constituents of the essential oil were determined and antimicrobials effects was studied by Heterotrophic Plate Counts method. 


\section{A. Plant Material}

Fresh aerial parts of wild Ziziphora tenuior were collected in Southeast of Iran (Coordinates: $27^{\circ} 56^{\prime}$ N57 52 E) in April 2014. Identification of the species was confirmed in Islamic Azad University, Kahnooj Branch. Samples were ground to a suitable size and stored in plastic container before analysis. The essential oils were extracted by hydro distillation by Clevenger-type apparatus of dried plant material for $3 \mathrm{~h}(40 \mathrm{~g}$ of sample in $350 \mathrm{~mL}$ of distilled water). The oil was separated from water by using n-hexane and then oils were dried by anhydrous sodium sulfate and stored in sealed glass vials at $4-5^{\circ} \mathrm{C}$ prior to analysis.

\section{B. Gas Chromatography-Mass Spectrometry}

Analysis of the essentials oils was performed using a Shimadzu GC-17A equipped with a Shimadzu GCMSQP 5050A mass selective detector and a HP-5 MS capillary column $(30 \mathrm{~m} \times 0.25 \mathrm{~mm}$, film thickness $0.25 \mu \mathrm{m})$. For GC/MS detection, an electron ionization system with ionization energy of $70 \mathrm{eV}$ was used. Helium at a flow rate of 0.8 $\mathrm{mL} / \mathrm{min}$ was used as carrier gas. Injector and MS transfer line temperatures were set at 250 and $270{ }^{\circ} \mathrm{C}$, respectively. Oven program temperatures were the same as for the GC analysis. Diluted samples $(1 / 10$ acetone, $\mathrm{v} / \mathrm{v})$ of $0.2 \mu \mathrm{L}$ were injected automatically in the split mode. The components were identified by comparing their relative retention times and mass spectra with those of standards (for the main components), Wiley library data of the GC/MS system, Kovats Index and literature data. All the tests were performed in triplicate.

\section{Antimicrobial effect by Heterotrophic Plate Counts (HPC) Method}

The antimicrobial activity was carried out by using the HPC method. For this purpose, the field cultivation $t R_{2} A$ and nutrient agar to be sterilized in autoclave in $60{ }^{\circ} \mathrm{C}$, after 4 hours cold it to the $20^{\circ} \mathrm{C}$. Then $10 \mathrm{ml}$ of sample of water with $0.02,0.04,0.06,0.08,0.1$, and $0.2 \mathrm{ml}$ of essential oil increase to the field cultivation in pottery dishes. Rested sample in the autoclave in $35 \pm 0.5{ }^{\circ} \mathrm{C}$ for $48 \pm 3$ hours. We counted the colony of microorganisms under the microscope and identified minimal inhibition concentration for essential oil of Ziziphora tenuior in water for microorganisms [18], [19].

\section{RESULTS AND DISCUSSION}

Ziziphora tenuior samples were collected after initial preparation isolated from the aboveground plant parts and plant samples preparation by water distillation using Clevenger apparatus after determining the optimal conditions for making essential oil was obtained. Essential oil with an efficiency of $1 / 1$ percent $(\mathrm{g} / \mathrm{g}$ ) was obtained and by GC-MS to determine the composition of the essential oils was analyzed. GC chromatogram of the essential oil of $Z$. tenuior showed in Figure I and the analysis results of the essential oil of Z.tenuior can be seen in Table I.

Results from the plant oils, indicates 21 effective combinations of Z.tenuior essential oils that have a considerable amount of the phenolic compounds that this indicates that there is anti-microbial or anti-fungal nature of the essential oils of Z.tenuior.

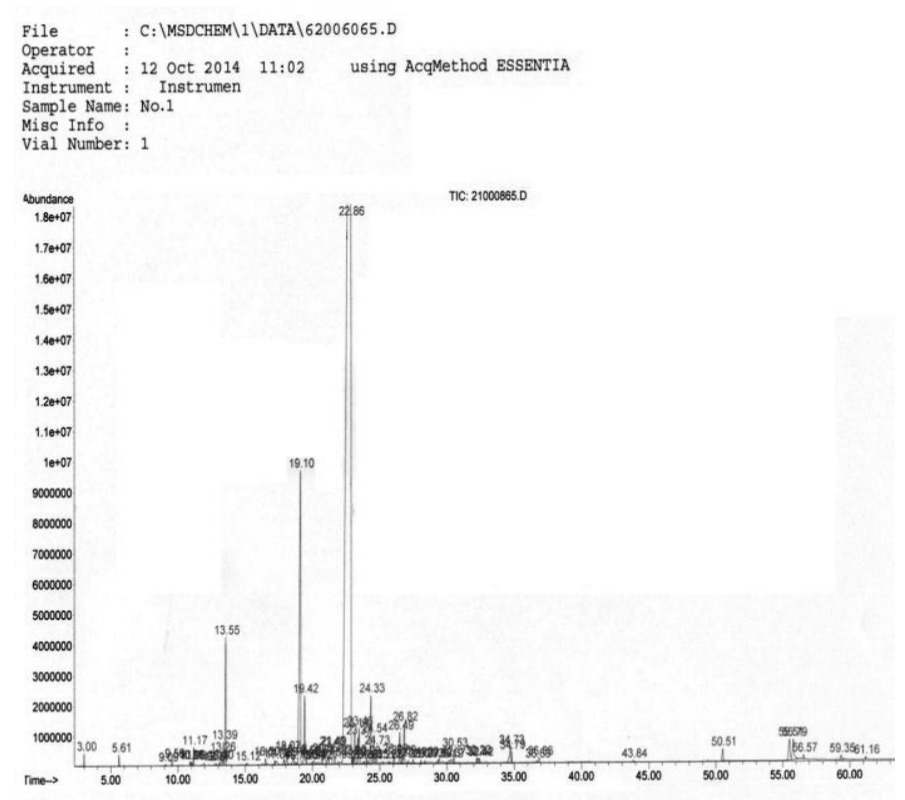

Fig. 1. GC Chromatogram of the Essential Oil of Ziziphora tenuior.

Major compounds in the oils of this plant include: Pulegone with $69.9 \%$ and Limonene with $4.8 \%$.

TABLE I: CHEMICAL COMPOSITION OF HYDRODISTILLATION ESSENTIAL OIL OF ZIZIPHORA TENUIOR

\begin{tabular}{|c|c|c|c|}
\hline No. & Compounds & RI & $\%$ \\
\hline 1 & Tricyclene & 925 & 0.7 \\
\hline 2 & $\alpha$-thujene & 930 & 0.5 \\
\hline 3 & $\alpha$-pinene & 937 & 3.4 \\
\hline 4 & Sabinene & 968 & 1.5 \\
\hline 5 & $\beta$-pinene & 977 & 1.8 \\
\hline 6 & Myrcene & 993 & 2.2 \\
\hline 7 & Limonene & 1021 & 4.8 \\
\hline 8 & Isopulegone & 1066 & 1.2 \\
\hline 9 & Terpinolene & 1081 & 3.1 \\
\hline 10 & Pulegone & 1213 & 69.9 \\
\hline 11 & 2-cyclohexen & 1248 & 4.1 \\
\hline 12 & $\alpha$-copaene & 1334 & 0.2 \\
\hline 13 & $\beta$-bourbonene & 1388 & 0.3 \\
\hline 14 & Benzenepropanoic acid & 1392 & 1.2 \\
\hline 15 & trans-caryophyllene & 1398 & 0.1 \\
\hline 16 & $\alpha$-humulene & 1417 & 0.1 \\
\hline 17 & $\beta$-cubebene & 1431 & 1.4 \\
\hline 18 & Germacrene D & 1492 & 1.8 \\
\hline 19 & $\gamma$-cadinene & 1516 & 0.9 \\
\hline 20 & Caryophyllene oxide & 1578 & 0.5 \\
\hline 21 & Hexadecanoicacid & 1682 & 0.3 \\
\hline
\end{tabular}


Pulegone is a naturally occurring organic compound obtained from the essential oils of a variety of plants such as Nepeta cataria, Lamiaceae, and pennyroyal [20], [21]. It is classified as a monoterpene. Pulegone is a clear colorless oily liquid and has a pleasant odor similar to pennyroyal, peppermint and camphor. It is used in flavoring agents, in perfumery, and in aromatherapy. It was reported that the chemical is toxic to rats if a large quantity is consumed [22]. Pulegone is also an insecticide the most powerful of three insecticides naturally occurring in many mint species [23].

Limonene is a colourless liquid hydrocarbon classified as a cyclic terpene. The more common d-isomer possesses a strong smell of oranges [24]. It is used in chemical synthesis as a precursor to carvone and as a renewables-based solvent in cleaning products. Limonene is a relatively stable terpene and can be distilled without decomposition, although at elevated temperatures it cracks to form isoprene [25]. It oxidizes easily in moist air to produce carveol, carvone, and limonene oxide [26]. With sulfur, it undergoes dehydrogenation to p-cymene [27]. Limonene is common in cosmetic products. As the main odor constituent of d-limonene is used in food manufacturing and some medicines, e.g. as a flavoring to mask the bitter taste of alkaloids, and as a fragrance in perfumery, aftershave lotions, bath products and other such products that include fragrance; it is also used as botanical insecticide, the $\mathrm{d}$ enantiomer is most active as an insecticide. It is added to cleaning products such as hand cleansers to give a lemon-orange fragrance and because of its ability to dissolve oils. In contrast, l-limonene has a piney, turpentine-like odor. In natural and alternative medicine, d-limonene is marketed to relieve gastro esophageal reflux disease and heartburn [28].

In other hand these components have been reported to have antimicrobial effects on bacteria and fungi and any microorganisms in water.

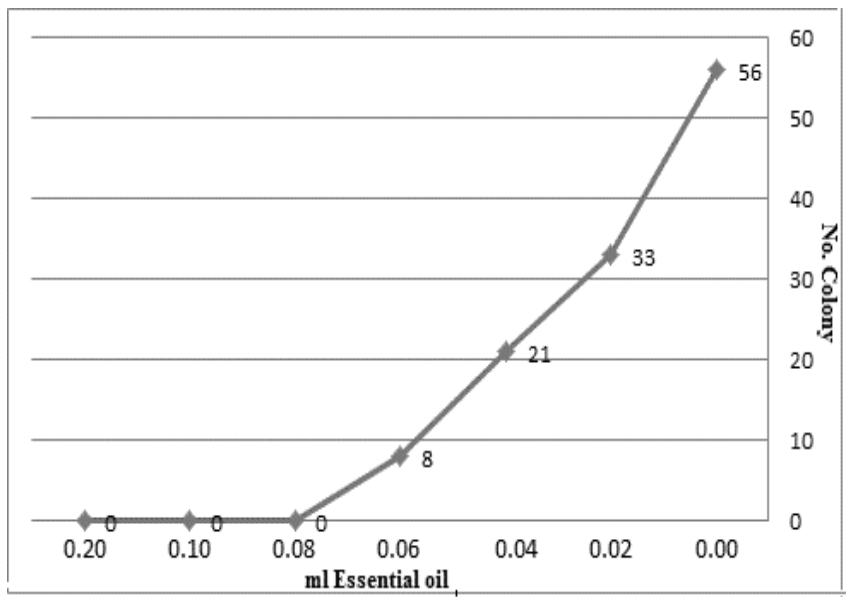

Fig. 2. Results of antimicrobial effect of essential oil of Ziziphora tenuior by heterotrophic plate ounts method.

According to (Fig. 2) this essential oil in $0.08 \mathrm{ml}$ concentration could eliminate microorganism in water.

\section{CONCLUSIONS}

The chemical composition of the essential oil of Ziziphora tenuior growing southeast of Iran was investigated. The data obtained in this study showed that the essential oil of aerial part of Z. tenuior has variability of hydrocarbons and can be a good source of them.

Z.tenuior is one of herbs which several studies in various fields have been done on it, especially in Iran. One such study was conducted by $\mathrm{P}$. Babakhanlou et al. that the phyto chemical studies on the one species of Z.tenuior around Tehran that used organs were aerial parts of the plant and using the water and steam distillation method of Kasier and Lang was done essential oils making that the extracted essential oils with yield about $80 \%$ relative to the dry weight of plant and key combinations were as: pulegone $(82.6 \%)$, limonene $(6.8 \%)$, cineol (1.9\%) which was extracted [29]. In same research Karimi et al. has a study on Z.tenuior and GC-MS analysis of hydro distilled essential oil derived showed twenty five known compounds in. Pulegone, iso menthone, limonene, and 8-hydroxy-delta-4(5)-p-menthen -3-one were major compounds. In aromatic water of Z.tenuior showed hypo cholesterol emic and overt hypo tri glyceride emic effects [30].

Compounds identified in essential oils of the aerial parts of Z.tenuior are close tithe research conducted by Babakhanlou et al. However, there are significant differences in the amount of compounds that can be caused by climatic differences, environmental factors and harvest time.

Due to the extent of the inhibitory effect of the oil on micro-organisms being attributed to the presence of aromatic nuclei containing a polar functional group, it can be awaited that the studied essential oil would exhibit good antimicrobial properties, this study showed that the antimicrobial effect of essential oil of aerial parts of Z.tenuior shoots high level of phenolic compounds present in the oil is fully compatible and these compounds and their effects on micro-organisms in tap water can be used in the future to clean municipal water but for use of this essential oil in various industries.

\section{ACKNOWLEDGMENT}

The authors would like to acknowledge Islamic Azad University, Kahnooj Branch (Iran) and Young Researchers and Elite Club, Kahnooj Branch (Iran) for financial support of this research.

\section{REFERENCES}

[1] O. Y. Celiktas, E. E. H. Kocabas, E. F. Bedir, T. V. Sukan, and K. H. C. Baser, "Antimicrobial activities of methanol extracts and essential oils of Rosmarinus officinalis, depending on location and seasonal variations," Food Chemistry, vol. 100, pp. 553-559, 2007.

[2] M. Shafei, A. Sharifan, and M. A. Meshki, "Composition of essential oil of Ziziphora clinopodioides and its antimicrobial activity on Kluyveromyces marxianus," Food Technology \& Nutrition, vol. 9, no. 1, pp. 101-107, 2012.

[3] G. R. B. Khaniki, F. Sefidkon, and Z. Dehghan, "The effects of some ecological factors on essential oil yield and composition of Ziziphora clinopodioides Lam," Journal of Herbal Drugs, vol. 1, pp. 11-20, 2010.

[4] V. Mozaffarian, Dictionary of Iranian Plant Names, Farhang Moaser Publishers, Tehran, Iran, 1996.

[5] K. H. Rechinger, Ziziphora in: Flora Iranica, no. 150, pp. 480-493, Academisch Druck University of Verlagsanstatt Graz, Austria, 1982.

[6] S. E. Sajadi, N. G. Dehkordi, and M. Baluchi, "Volatile constituents of Ziziphora clinopodioides lam," Journal of Pajhoohesh va Sazandegi, vol. 58, no. 1, pp. 97-100, 2003.

[7] M. E. Duru, M. Ozturk, and O. Ceylan, "The constituents of essential oil and invitro antimicrobial activity of Micromeria Cilicia from Turky," Journal of Ethnopharmacology, vol. 94, no. 1, pp. 43-48, 2003. 
[8] M. Chitsaz, M. D. Barrton, M. Naseri, M. K. Nejhad, and M. Bazargan, "Essential oil composition and antibacterial effects of Ziziphora clinopodioides Lam," presented at $17^{\text {th }}$ European Congress of Clinical Microbiology and Infectious Diseases ICC, Munich, Germany, Abstract number: 1733-303, 2007.

[9] E. Gozed, N. Yavasoglu, K. Ulku, and B. Ozturk, "Antimicrobial activity of endomic Ziziphora taurica subsp. Cleonioides (boiss.) P. H.D avis Essential oil," Acta Pharmaceutica Sciencia, vol. 48, pp. $55-62,2006$.

[10] K. Javidniua, "Identify compounds found in essential oils Ziziphora teniur, Zataria multiflora and Matricaria decipiens and Antimicrobial them," Ph.D. Dissertation, Field of Pharmacy, Tehran University of Medical Sciences, 1996.

[11] M. Friedman, R. P. Henika, and E. R. Mandrell, "Bactericidal activities of plant essential oils and some of their isolated constituents against Campylobacter jejuni, Escherichia coli, Listeriamonocytogenes, and Salmonella enterica," Journal of Food Protect, vol. 65, pp. 1545-1560, 2002.

[12] C. C. Tassou, H. E. Drosinos, and J. G. Nychas, "Effects of essential oil from mint (Mentha piperita) on Salmonella enteritidis and Listeria monocytogenes in model food system at 4 degrees and 10 degrees $\mathrm{C}$," Journal of Applied Bacteriology, vol. 78, pp. 593-600, 1995.

[13] S. Grujić-Jovanović, D. H. Skaltsa, P. Marin, and M. Soković, "Composition and antibacterial activity of the essential oil of six Stachys species from Serbia," Flavour and Fragrance Journal., vol. 19, pp. 139-144, 2004

[14] D. Kalemba and A. Kunicka, "Antibacterial and antifungal properties of essential oils," Current Medicinal Chemistry, vol. 10, pp. 813-829, 2003.

[15] J. U. Duncombe, "Infrared navigation - Part I: An assessment of feasibility (Periodical style)," Electron Devices, vol. 11, pp. 34-39, 1959.

[16] P. Babakhanlou, M. Mirza, F. Sefidkon, L. Ahmadi, M. M. Barazandeh, and F. Asgari, "Evaluation of essential oil constituents Ziziphora tenuior L.," Iranian Journal of Medicinal and Aromatic Plants Research, vol. 2, no. 4, pp. 103-114, 1999.

[17] J. C. Maruzzella, J. Balter, and A. Katz, "The action of perfume-oil vapours on fungi," American Perfumer and Aromatics, vol. 74, pp. $21-22,1959$.

[18] H. M. Pourramazani and A. Ganjali, "Antimicrobial effect of essential oil of artemisia kermanensis on water by HPC method," Research in Pharmaceutical Sciences, vol. 7, no. 5, pp. 849-854, 2002.

[19] J. C. Maruzzella and N. A. Sicurella, "Antibacterial activity of essential oil vapors," Journal of American Pharmaceutical Association, Scientific Edition, vol. 49, pp. 692-694, 1960.

[20] F. Grundschober, "Literature review of pulegone Perfum," Flavorist, vol. 4, pp. 15-17, 1979.

[21] J. B. Sullivan, B. H. Rumack, H. Thomas, R. G. Peterson, and P. Brysch, "Pennyroyal oil poisoning and hepatotoxicity," Journal of the American Medical Association, vol. 242, no. 26, pp. 2873-2874, 1979.

[22] I. Thorup, G. Würtzen, J. Carstensen, and P. Olsen, "Short term toxicity study in rats dosed with pulegone and menthol," Toxicology Letters, vol. 19, no. 3, pp. 207-210, 1983.

[23] G. Franzios, M. Mirotsou, E. Hatziapostolou, J. Kral, Z. G. Scouras, and P. Mavragani-Tsipidou, "Insecticidal and genotoxic activities of mint essential oils," Journal of Agricultural and Food Chemistry, vol. 45, no. 7, pp. 2690-2694, 1997.
[24] K. G. Fahlbusch, F. J. Hammerschmidt, J. Panten, W. Pickenhagen, D. Schatkowski, K. Bauer, D. Garbe, and H. Surburg, "Flavors and Fragrances," Ullmann's Encyclopedia of Industrial Chemistry, 2003.

[25] H. Pakdel, "Production of dl-limonene by vacuum pyrolysis of used tires," Journal of Analytical and Applied Pyrolysis, vol. 57, pp. 91-107, 2001.

[26] Karlberg, "Ann-Therese; Magnusson, Kerstin; Nilsson, Ulrika. Air oxidation of d-limonene (the citrus solvent) creates potent allergens," Contact Dermatitis, vol. 26, no. 5, pp. 332-340, 1992.

[27] A. W. I. Weitkamp, "The action of sulfur on terpenes. the limonene sulfides," Journal of the American Chemical Society, vol. 81, no. 13, p. $3430,1959$.

[28] J. Sun, "d-Limonene: safety and clinical applications," Alternative Medicine Review: Journal of Clinical Therapeutic, vol. 12, no. 3, pp. 259-264, 2007.

[29] M. Kienholz, "Studies on the antibacterial action of ethereal oils," Arzneimittel Forschung Drug Research, vol. 9, pp. 519-521, 1959.

[30] I. Karimi, H. Hayatgheybi, S. Motamedi, D. Naseri, T. Shamspur, D. Afzali, and A. Hassanpour-aghdam, "Chemical composition and hypolipidemic effects of an aromatic water of Ziziphora tenuior $L$. in Cholesterol-fed Rabbits," Journal of Applied Biological Sciences, vol. 7, no. 3, pp. 61-67, 2013.

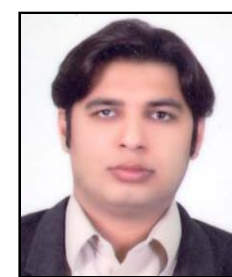

Amin Ganjali studied analytical chemistry at the University of Sistan \& Baluchestan, Iran. His research interests are focused on extraction and study of herbal plants. Mr. Ganjali is a member of Iranian chemical society and Young Researchers and Elite Club. Now $\mathrm{He}$ is currently a lecturer in the Department of Experimental Science of Islamic Azad University, Kahnooj Branch.

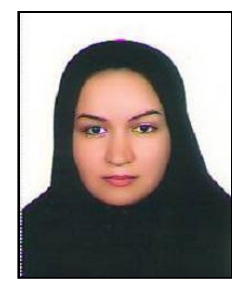

Maryam Pourramezani Harati studied analytical chemistry at the University of Sistan \& Baluchestan, Iran. His current researches are focused on extraction and study of herbal plants. Mrs. Pourramazani Harat is a member of Young Researchers and Elite Club.

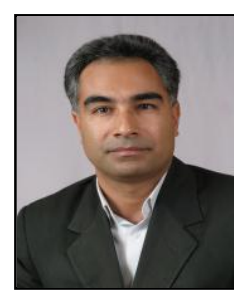

Massoud Kaykhaii studied analytical chemistry at the Ferdowsi University, Iran and passing postdoctoral in University of Tasmania, Australia. His current researches are focused on development and application of new sample preparation techniques including: "Liquid Phase Microextraction (LPME)"; "Solid Phase Microextraction (SPME)"; "Membrane Extraction with Sorbent Interface (MESI)". He is a member of Iranian Chemical Engineers, Society for Adhesion and Adhesives (UK), American Chemical Society and he is the editor-in-chief of Journal of Advanced Researched in Analytical Chemistry. Now he is an associate professor in Department of Chemistry, University of Sistan and Baluchestan. 